\title{
STUDY OF POTENTIAL MELAYU VILLAGE AS A HERITAGE AREA IN SEMARANG
}

\author{
N. Anggita ${ }^{a}$, N. Yuliastuti ${ }^{a}$ \\ a Universitas Diponegoro, Indonesia
}

\section{Article Info:}

Received: 14 August 2017

in revised form: 1 January 2018

Accepted: 30 March 2018

Available Online: 30 April 2018

\section{Keywords:}

urban village, heritage area,

cultural heritage, Semarang

\section{Corresponding Author:}

Nuzulia Anggita

Diponegoro University,

Semarang, Indonesia

Email:

nuzulia.anggita16@pwk.undip.ac.

\begin{abstract}
The urban village is a settlement that was established in the early period of the formation city and is the embryo of Semarang. Melayu Village is a heritage area where the existing heritage assets is inseparable from the history of the past. The enviromental of Melayu Village is quality conditions suffered environmental degradation because the threat of catastrophic tidal flood, the level of residential density is high, and there are several old buildings that were damaged. Assets contained in this region shows the evolution of human life and settlements from time to time that are still functioning properly. The purpose of this study to assess the potential in Melayu Village as a heritage area. This study uses descriptive quantitative and spatial analysis. The results of this study indicate that RW IV and RW VII are potentially as a heritage district with a score of 2.4 that characterized by a sociocultural conditions that their religious activities in the form of cultural activities. This is also supported by the discovery of artifacts buildings in RW VII that Layur Tower Mosque and Shrine Kam Hok Bio who survived and functioned until today. Based on the potential of Melayu Village already should be protected as a heritage area.
\end{abstract}

Copyright (C) 2018 GJGP-UNDIP This open access article is distributed under Creative Commons Attribution (CC-BY-NC-SA) 4.0 International license.

Anggita, N., \& Yuliastuti, N. (2018). Study of potential melayu village as a heritage area in Semarang. Geoplanning: Journal of Geomatics and Planning, 5(1), 43-52. doi:10.14710/geoplanning.5.1.43-52.

\section{INTRODUCTION}

The city is a permanent settlement, dense, have buildings to accommodate a wide range activity of the population (Roth, 1992). Kampung in Semarang City is a neighborhood settlements built without planning and embryonic development of the city of Semarang. The old village is part of the hometown as one of the models dualism hometown in Indonesia (Vecco, 2010). Their spatial identity is motivated by socio-cultural and historical conditions encourage the presence of a village. The existence of the old village reflects how old hamlet able to survive in the midst of modern urban development with the values that exist in the life of local communities where these values appear as a result of human interaction, activities and sociocultural background. Regional heritage is the forerunner of city life over time expanded and continues to grow. The existence of the village is supported by the potential of existing heritage area. Regional heritage in a city is a testament to the development of a city seen from: (a) the initial formation of the city; (b) the potential beginning of a city; (c) strategic areas in a city; (d) the socio-cultural life of society. Regional heritage in a city is a testament to the city's development. This area to witness the events that occurred in the vicinity. Life in the village is inseparable from the values of life who inherited their parents' past and potential regional heritage is now materialized in the form of physical, social, cultural, and economic in their daily activities.

Urban village located in the Dadapsari Village an old and historic villages namely Melayu Village. In Semarang City Regulation No. 14 In 2011, Melayu Village serve as a cultural heritage area. This is supported by the buildings that have historical value to the function as a place of worship called Layur Tower Mosque and Kam Hok Bio Temple. The building is still used and put to good use as needed. Environmental quality conditions Melayu Village decreased environmental quality due to the threat of floods rob, high building density levels, and the presence of some old buildings that are changing the face shape of the building. 
Under the conditions of environmental degradation is getting worse and will reduce the values contained in Melayu Village. The aim is to assess the potential long as regional heritage village in Melayu Village.

Heritage is an asset that shows the evolution of human life and settlement over time, influenced by physical barriers and potential of their natural environment and addressed through the power of social, economic and cultural both external and internal. In that sense heirloom contains some important values, namely the evolution of human life, housing, physical potential and the environmental, social, economic and cultural. That is the legacy not only related to physical or tangible, but intangible form of cultural, economic and social life. Regional heritage can reflect the characteristics of a city setting a culture, have a unique local characteristics marked by the discovery of evidence inscription censure events. In addition, there are artifacts, historic buildings, places of worship, monuments, gates, market, square or a place that has character with an atmosphere that is positive for the community. Heirloom region contained some important values in the form of potential physical and environmental, cultural, social, and economic. Regional heritage reflects the characteristics of the city setting and has a distinctive local characteristics culture (Gordon \& Rapoport, 1979). There are four heritage area, as follows; own buildings and groups of buildings; small village as the center of history; the cities heritage; and heritage district in a big city (Papageorgiou-Venetas, 1971).

Heritage area has significance to the life of an old village. Regional heritage does not only present how a community can survive the development of the city by using the values that have been institutionalized in the society, but is able to characterize the identity of an area. The physical characteristics were studied in an area is a part of a city. Town-forming elements such as buildings, roads, boundaries, building density, land use, the legality of land affecting an area. Maintaining the existence of the old village needs to be done, where necessary integration of the role of government and society in order to create an old village hometown potentially life as heritage area. The role of government to Melayu Village Melayu Village is the establishment of a cultural heritage area in the Regional Regulation No. 14 Year 2011, which is the regional development potential inheritance. Programs related to the regulation as a heritage building improvement program in Melayu Village is Mosque Layur tower in 2006. It takes the government's efforts to encourage the preservation of the old village in order to improve the local economy and the quality of the environment. The government plays a role through policy and legislation. The community plays a role through awareness in appreciating the cultural heritage, motivate yourself to potential support existing heritage area to retain its identity (Karmadi, 2007).

\section{DATA AND METHODS}

Study of potential long as the village's heritage department uses a quantitative approach. The method used is quantitative descriptive analysis method. Quantitative descriptive analysis transforms raw data into a data form that is easily understood and interpreted and presented into a clear information (Kusmayadi \& others, 2000). Methods of data collection consists of primary and secondary. Primary data collection technique using observation, interviews, and questionnaires by using sampling techniques. Sampling technique used is purposive sampling techniques nonprobability. The research sample is needed because the number of respondents in a population in Melayu Village at 7602 number of families so difficult when examined one by one.

The village has a close relationship one limited citizens association called RW (Sihombing, 2002). Therefore, in the sample set of 99 number of families are scattered in the called RW. Secondary data collection techniques such as structured interviews carried out to head of community, heads of RT or RW, Head of Dadapsari Sub-district, Bappeda Semarang are considered capable of providing knowledge to the study area of research. The analytical method used is quantitative descriptive analysis tools weighting using Likert Scale.

Data were analyzed using the Likert Scale Level 3 selected as the community of Melayu Village poorly educated majority. So that level 3 is considered appropriate to examine people with low education levels (Widoyoko, 2012). The class interval score levels are divided into 3 scores range from 1 to 1.7 with not 
potential criteria or bad, scores range 1.8-2.3 with potentially enough criteria or moderate, and scores range from 2.4 to 3 criteria potential or good. Level score calculation using the following formula:

RW Variable Total Score $=$ Total score of all indicators RW-n / Number of indicators

\section{RESULTS AND DISCUSSION}

\subsection{History of Melayu Village}

Melayu Village which is the embryonic development of Semarang city in the 17th century, is now divided into 6 RW which is in the Village Dadapsari namely RW II. RW III, IV RW, RW VI, VII RW, and RW VIII. Melayu Village administrative Size $46.043 \mathrm{~km}^{2}$ and a population density of $736.78 \mathrm{~km}^{2}$. Based on the historical development of Melayu Village in the 17th century until the 20th century overlay results obtained in Figure 1. Melayu Village is a village that has characteristics as the old village. In the 17th century there are only a few plots of settlements ethnic Arabs who dominate the eastern Hadramaut Melayu Village adjacent to Kali Semarang. Kali Semarang is a means of water transport which functioned as ship traffic will stop in the city of Semarang. Later in the 18th century began to grow around the corridors Layur settlements because there are many people who come to Melayu Village. Then to enter the 19th century further grow and develop towards the west and spread into 6 RW. In the 19th century already visible Melayu Village condition that has developed in the mark with their activities in Melayu Village. At the end of the 20th century to the present condition of Melayu Village been very solid which consists of several small villages in the 6 RW spread in Melayu Village.

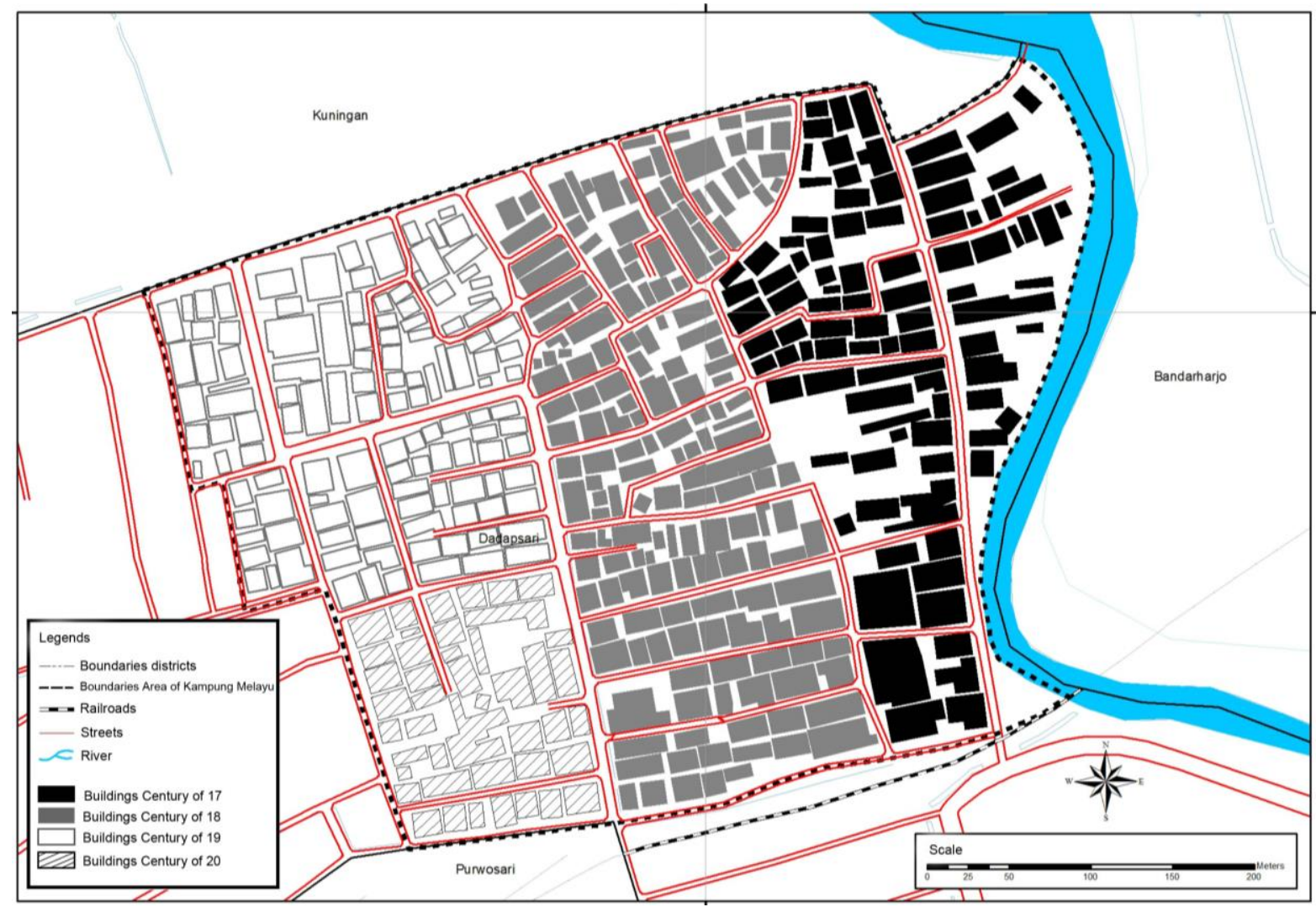

Figure 1. The Map of Development History in Melayu Village

\subsection{Building Conditions}

The existence of Melayu Village in downtown Semarang be a challenge for the impending development. Problems for Melayu Village reduced values of the buildings contained in Melayu Village. Along with the development of the city, the majority of the building with the old architecture has begun to change into 
modern architecture. This reduces the value of a heritage area. RW but some still retain the old architecture which has a facade that reflects the communities living. The architecture of the building marked with the building facade or face shape convey cultural situation when buildings are constructed (Krier \& Vorreiter, 1988). The facade of the building reflects the image of a building. The condition of buildings in Melayu Village as the old village still owns the building with a facade that reflects the culture of the people that is building facade Java, building facade Hadramaut Arabic, Chinese and building facade building facade Banjar located in RW IV, VII RW, and RW VIII. So it can be seen the condition of the buildings that still retain the old building facade renovation although there was little seen in Figure 2.

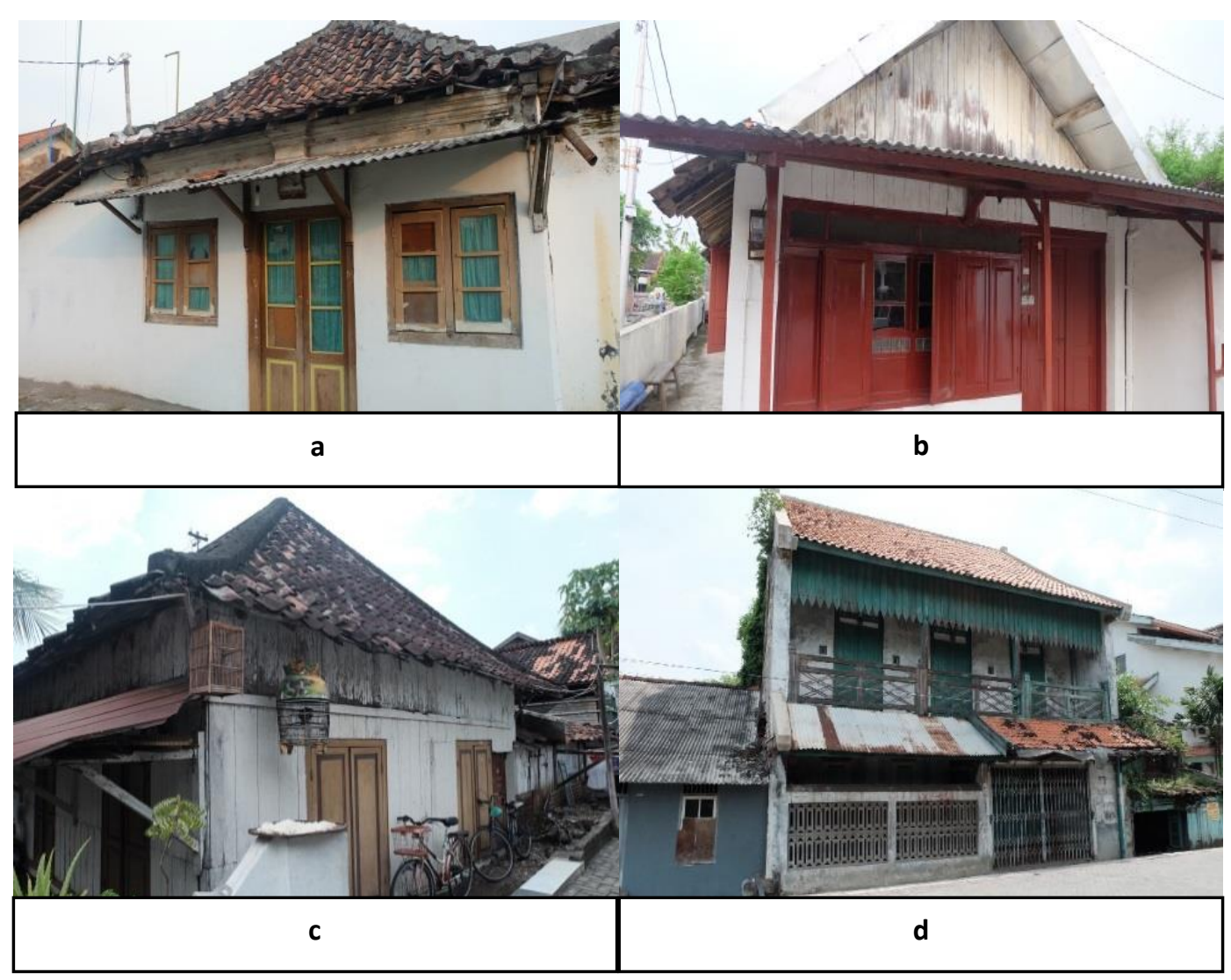

Figure 2. Building Facade Condition in Melayu Village (a) Building Facade Java in RW VII (B) Building Facade Arab Hadramaut RW VIII (c) Building Facade RW Banjar in IV (d) Building Facade Chinese in RW IV (Analysis, 2016)

The condition of the building is affected by the physical qualities of the building due to high population density so that the Basic Building Coefficient (KDB) a majority of more than $80 \%$ of homes and buildings do not have a yard. This has an impact on social interaction made public only in the streets, shops or stalls. In addition, the low level of the economy in Melayu Village broad impact on home ownership. The majority of residents of Melayu Village had a spacious house with a small category with a broad interval is $12 \mathrm{~m} 2-74$ $\mathrm{m} 2$ and is divided into 6 RW. So it can be seen the level of the condition of buildings in Melayu Village in Table 1.

In table 1 we can see aspects of the condition of buildings in Melayu Village, RW RW VII is that having the condition of the building with the highest score of 2.34, not much different from the condition of the building at RW IV and RW VIII were medium which has a score of 2.24 and 2.25 which means to have criteria for being. While at RW II, RW III, and RW VI relatively poorly given a score of 1.63, 1.85, and 1.69. This is because RW II, III RW, and RW VI so many have turned into a modern building architecture. Architectural buildings in RW is already not maintain the old building facade. Here is a map of the condition of buildings in Melayu Village shown in Figure 3. 
Table 1. Levels of Building Condition

\begin{tabular}{|ccc|}
\hline RW Category & Levels of Building Conditions & \multicolumn{2}{c|}{ Criteria } \\
\hline RW II & 1.63 & Bad \\
\hline RW III & 1.85 & Moderate \\
\hline RW IV & 2.24 & Moderate \\
\hline RW VI & 1.69 & Bad \\
\hline RW VII & 2.34 & Moderate \\
\hline RW VIII & 2.25 & Moderate \\
\hline
\end{tabular}

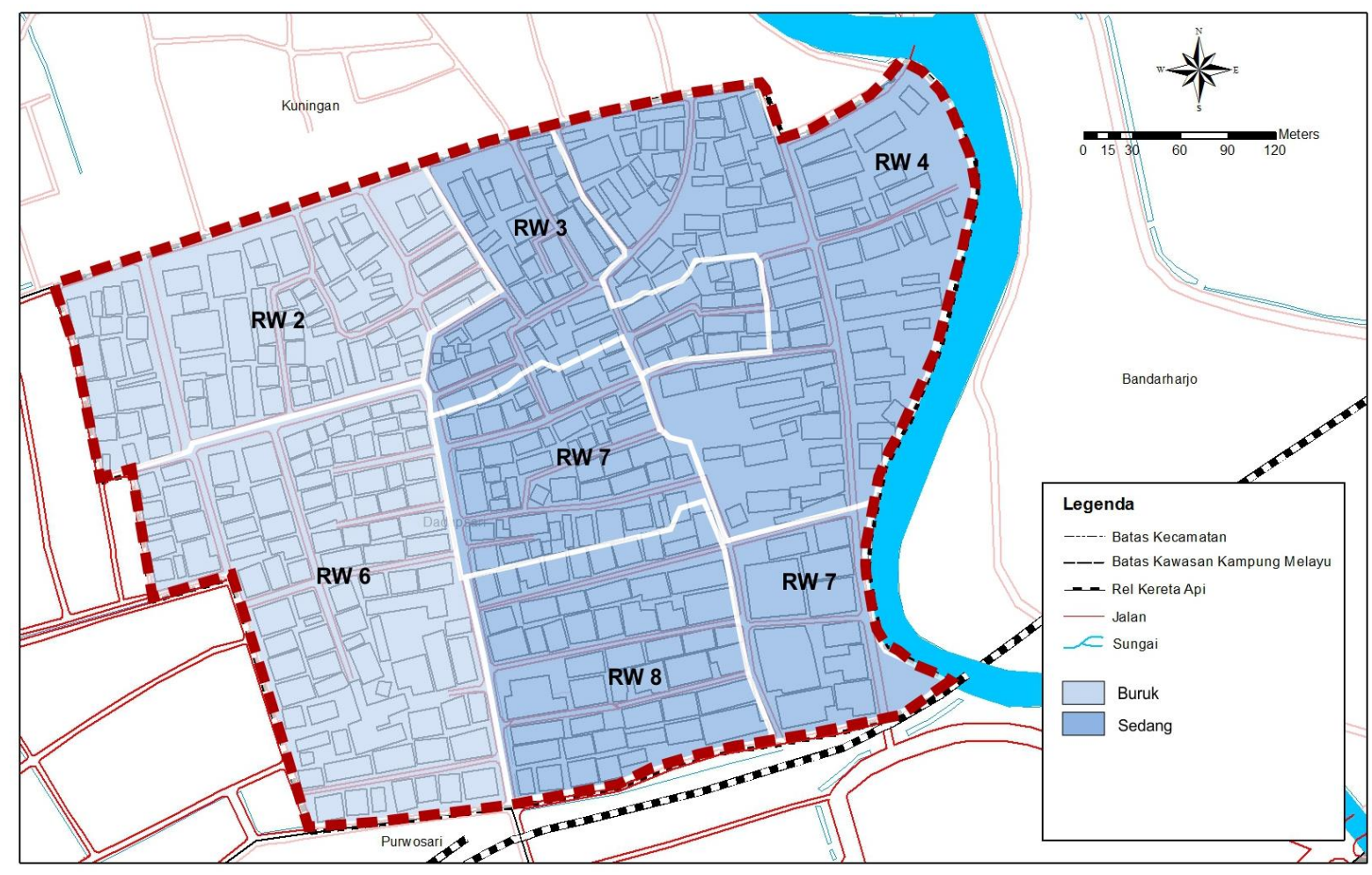

Figure 3. The Map of Conditions Building (Analysis, 2016)

\subsection{Socio-Cultural Conditions}

Social conditions consisting of interaction, solidarity and religious tolerance reflected in social conditions Melayu Village. Entire neighborhoods in Melayu Village have social activities such as recitation, Islamic art, gathering, and jimpitan. Begilir for their routine executed at houses. RT social gathering held in Melayu Village is conducted monthly by the PKK. Jimpitan activities by providing voluntary fund to the families bereaved as a concern among the public. Prominent ultural activities namely religious activities that can be seen in Figure 4.

Social activities related to the intensity of the activity of the community (Kristiani \& Yuliastuti, 2013). Interaction that takes place between the communities in the form of formal and informal interaction interactions. The village community life is usually characterized by the interaction due to sympathy or interest in understanding others. Social interaction is influenced by the environment crowded with diverse use of space (Talen, 1999). Social and cultural conditions are the most potent aspect in achieving the heritage district, following the level of social and cultural conditions in Melayu Village in Table 2. 


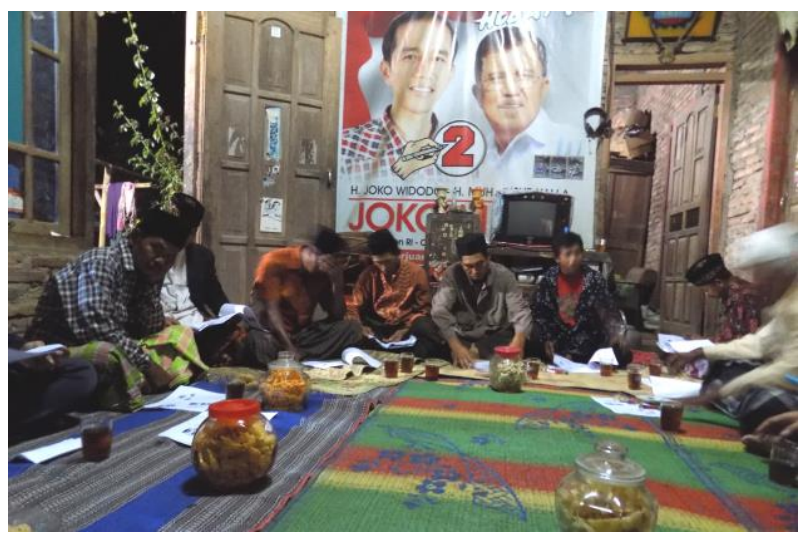

Figure 4. Religion Activities in Melayu

Table 2. Level of Socio-Cultural Conditions

\begin{tabular}{|ccc|}
\hline RW Category & Level of Socio-cultural Conditions & Criteria \\
\hline RW II & 2.29 & Moderate \\
\hline RW III & 2.46 & Good \\
\hline RW IV & 2.60 & Good \\
\hline RW VI & 2.30 & Moderate \\
\hline RW VII & 2.71 & Good \\
\hline RW VIII & 2.67 & Good \\
\hline
\end{tabular}

RW VII is RW that has socio-cultural aspects are quite good with a score of 2.71 in Table 2. It is because of RW VII active in social activities and their culture prevalent form of Islamic art. The constant routine in the community activities that exist in the Kampong and the high level of community participation in environmental activities had to be one reason for the formation of a strong membership (Kristiani \& Yuliastuti, 2014). While the VI RW and RW II has a socio-cultural aspects are classified as moderate with a score of 2.30 and 2.29, this is because most people are migrants and are less active in social activities. Here is a map of social and cultural conditions in Melayu Village shown in Figure 5.

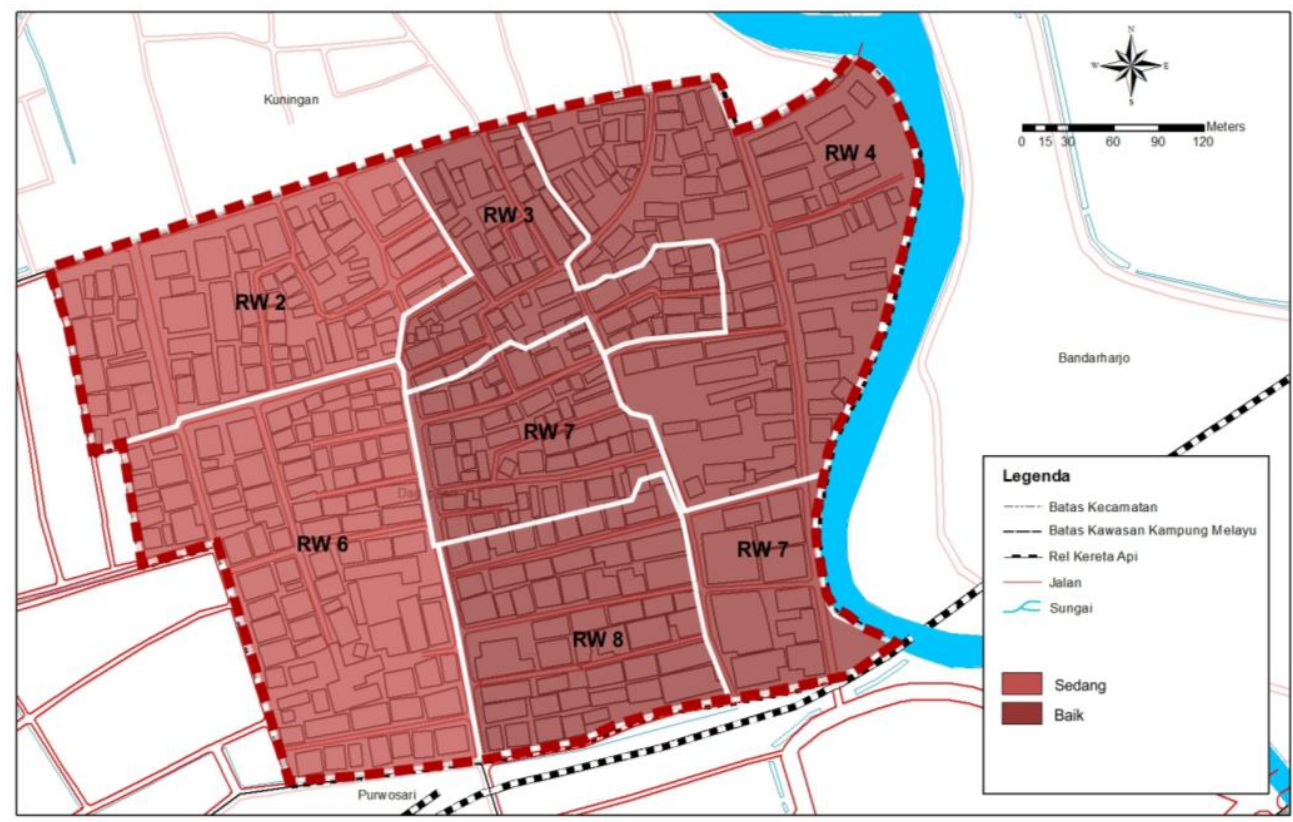

Figure 5. The Map of Culture Social Conditions in Melayu Village (Source: Analysis, 2016)

\subsection{Economics Conditions}


A society in neighborhoods should have a strong economy to maintain its viability, among others, by the availability of jobs, income levels are quite good, the development and implementation of appropriate technology (Lachman, 1997). RW VII traversed Layur Street is a street with high economic activity due to the growth of the trade and services. But not with RW II, RW III and IV RW, RW The third population rarely open a side business in addition to constrained funding lacked strategic location as a trade and services. Minimum Wage Semarang in 2016 amounted to IDR. 1,909,000.00 while the majority of residents of Melayu Village had similar income levels UMR Semarang or even lower for the majority of the Melayu Village livelihood as traders and laborers.

Table 3. Level of Economics Conditions

\begin{tabular}{|crcc}
\hline RW Category & Level of Economics Conditions & \multicolumn{2}{c|}{ Criteria } \\
\hline RW II & 1.49 & Bad \\
\hline RW III & 1.57 & Bad \\
\hline RW IV & 2.05 & Moderate \\
\hline RW VI & 1.48 & Bad \\
\hline RW VII \\
RW VIII & 2.18 & Moderate \\
\hline
\end{tabular}

Based on the analysis of the level of economic conditions in Table 3, the economic conditions in the VII RW RW that has the economy with the highest score of 2.18 is still relatively moderate, not much different from the economic conditions in RW IV and VIII were medium which has a score of 2.05 and 2.02. But it is already secured income above the minimum wage of Semarang and many have second jobs. almost reaching economic conditions so well seen from the level o While at RW II, RW III, and RW VI relatively poorly given a score of 1.49, 1.57, and 1.48. This is because RW II, RW III, and RW VI many of which have high levels of low income and do not have a side business. Here is a map of the economic conditions in Melayu Village shown in Figure 6.

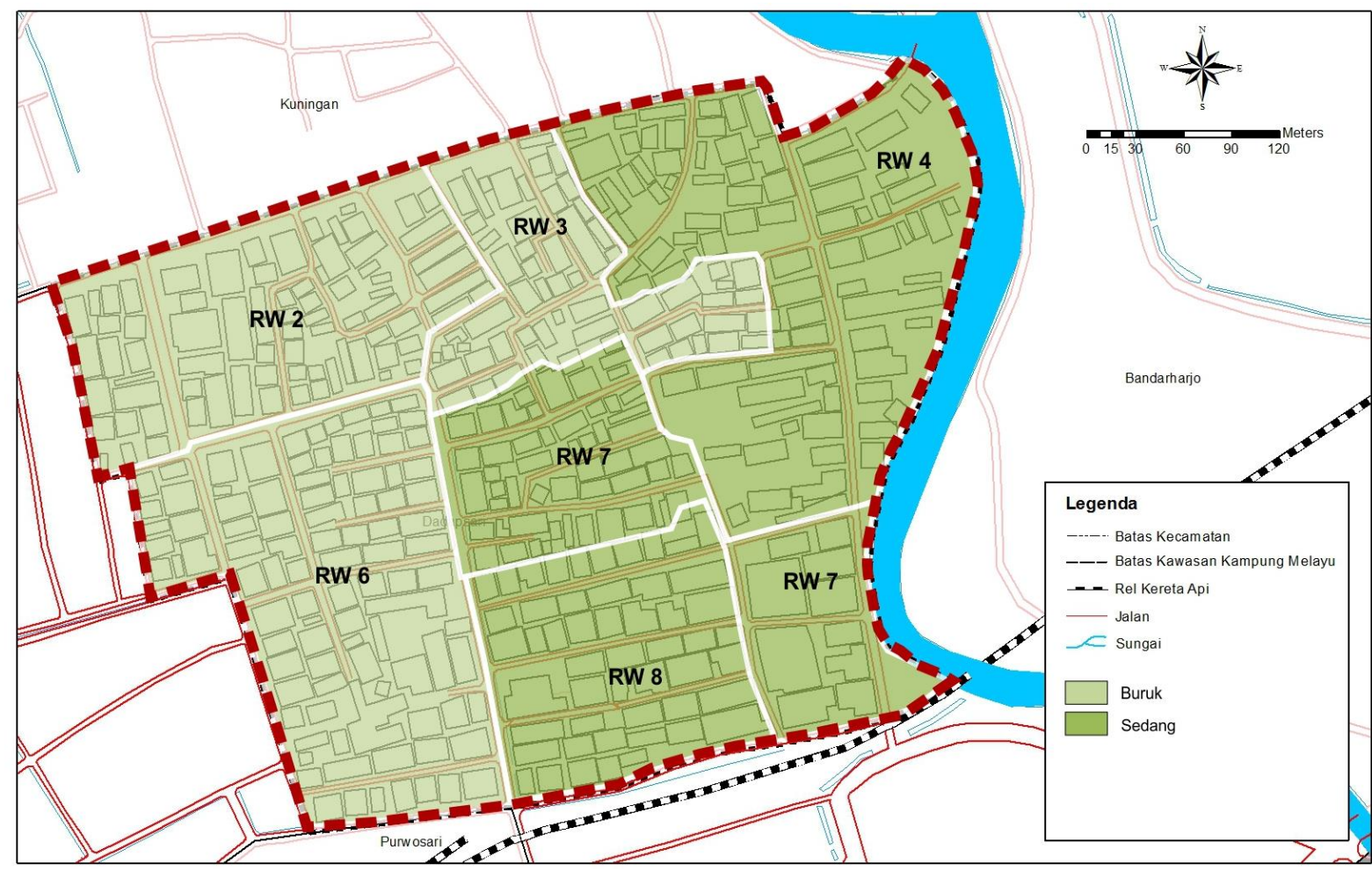

Figure 6. Map of Economic Conditions in Melayu Village (Source: Analysis, 2016) 
Regional heritage has significance to the life of an old village. Melayu Village is an old village that has potential as a heritage area in the city of Semarang. (Karmadi, 2007) said that supporting the heritage area, required the integration of the role of government and in order to create an old village life which still survive amid the development of Semarang to support heritage in Melayu Village area shown in Figure 7.

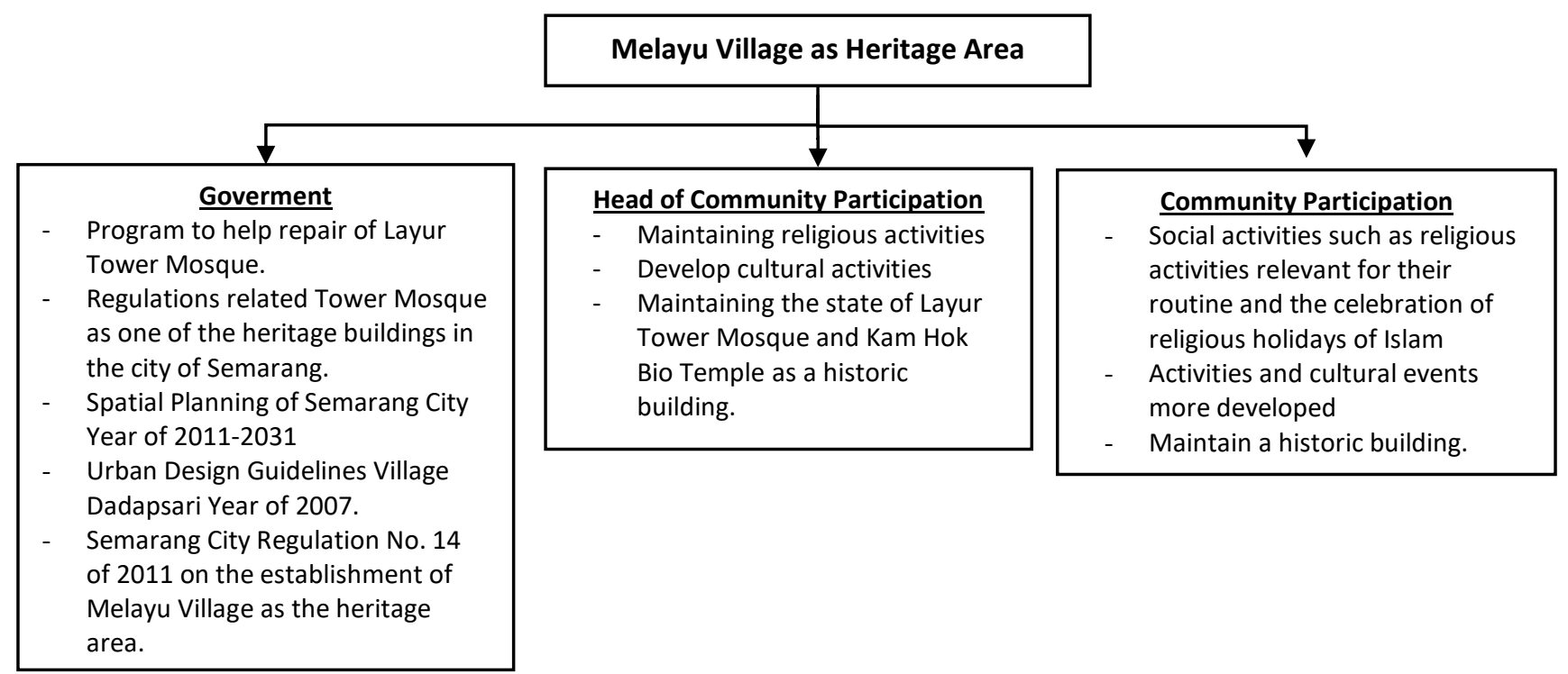

Figure 7. Community Participation and Goverment Support as Heritage Area (Source: Analysis, 2016)

Regional heritage can reflect the characteristics of a city setting a culture, have a unique local characteristics marked by the discovery of evidence inscription censure events. In addition, there are artifacts, historic buildings, places of worship, monuments, gates, market, square or a place that has character with an atmosphere that is positive for the community (Gordon \& Rapoport, 1979).

Table 4. Level of Potential Heritage Area

\begin{tabular}{|ccc|}
\hline RW Category & Level of Potential Heritage Area & Criteria \\
\hline RW II & 1.7 & Not Potentially \\
\hline RW III & 1.9 & Potentially Enough \\
\hline RW IV & 2.4 & Potentially \\
\hline RW V I & 1.8 & Potentially Enough \\
\hline RW VII & 2.4 & Potentially \\
\hline W VII & 2.3 & Potentially Enough \\
\hline
\end{tabular}

Based on Table 4 can be in the know that RW III, VI, and VIII ample potential as a heritage area with a score approaching 2.4. However, RW II no potential as a heritage area. However, RW IV and VII potential as a heritage district with a score of 2.4. This is because the condition of the existing building still retains the majority of the architecture of old buildings that reflect the activities of the society. This is supported by the heritage buildings in the form of artifacts Layur Tower Mosque and Kam Hok Bio Temple become more supportive as a heritage area. The social conditions of the people quite well because people feel comfortable to live, conduct formal and informal interactions with frequency levels frequently. Besides, social and cultural activities in RW IV and RW VII are also routinely performed. Cultural activities are typical of Islamic art Hadrahan or Terbangan. And economic conditions in RW VII leads to good economic conditions in which people have an income above the minimum wage of Semarang and supported by the sideline for RW VII located at Jalan Layur which is an area of trade and services in Melayu Village. While RW VIII has led to the region's potential inheritance by more favorable aspects to support the heritage area. And RW III and RW VI had not led to the region's potential inheritance for not maintaining heritage values contained therein and RW II that has no potential as a heritage area. From the region's potential inheritance level results can be seen the potential of heritage in Melayu Village area mapped in Figure 8. 


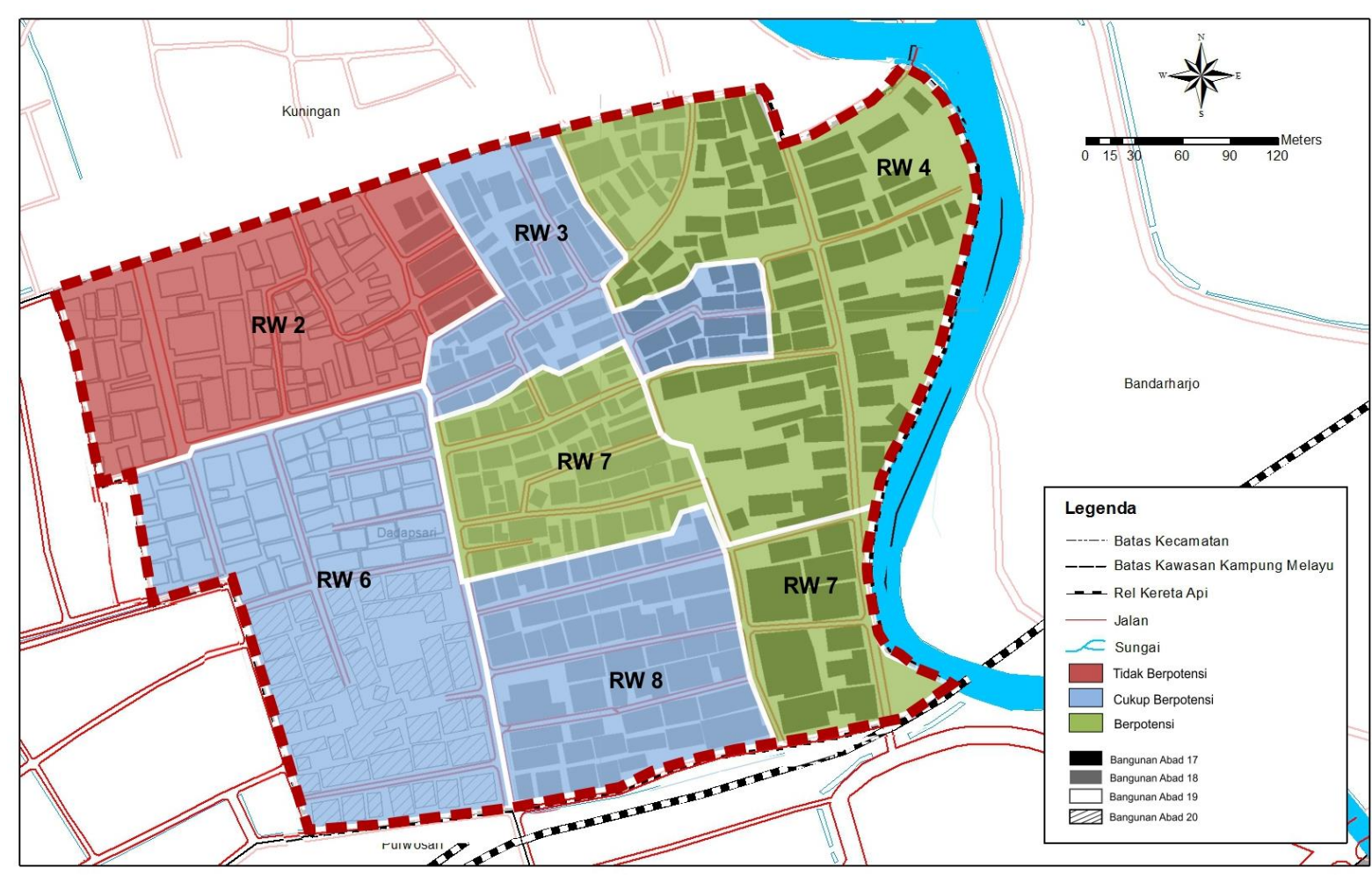

Figure 8. The Map of Potential Heritage Area in Melayu Village (Source: Analysis, 2016)

\section{CONCLUSION}

Based on the analysis, RW VII and RW VIII are RW potential as a heritage area with a score of 2.4. This is because the condition of the majority of the building still retains architecture of the old buildings that reflect the activities of the society. There is a heritage building in the form of artifacts and Shrine Mosque Tower Layur Kam Hok Bio become more supportive as a heritage area. The social conditions of the people quite well because people feel comfortable to live, conduct formal and informal interactions with frequency levels frequently. Besides, social and cultural activities in RW VII and RW VIII are also routinely do so more turn. And economic conditions that exist in both the RW leads to good economic conditions in which people have an income above the minimum wage of Semarang and supported by the sideline for RW VII located at Jalan Layur which is an area of trade and services in Melayu Village. Based on the analysis that has been done, in achieving the heritage area in Melayu Village supported by the government and community participation.

\section{ACKNOWLEDGMENTS}

Convey thanks to those who helped in the research, especially to all the residents of Melayu Village and tools that support the existence of the old hamlet of research as a potential area of this heritage.

\section{REFERENCES}

Gordon, C., \& Rapoport, A. (1979). Human Aspects of Urban Form: Towards a Man-Environment Approach to Urban Form and Design. Contemporary Sociology, 8(2), 313. [Crossref]

Karmadi, A. D. (2007). Budaya Lokal Sebagai Warisan Budaya dan Upaya Pelestariannya. Makalah Disampaikan Pada Dialog Budaya Daerah Jawa Tengah Yang Di Sel Enggarakan Oleh Balai Pelestarian Sejarah Dan Nilai Tradisional Yogyakarta Bekerjasama Dengan Dinas Pendidikan Dan Kebudayaan Propinsi Jawa Tengah, Di Semarang, 8-9.

Krier, R., \& Vorreiter, G. (1988). Architectural composition (Vol. 10). book, Rizzoli New York.

Kristiani, M. K., \& Yuliastuti, N. (2013). Kajian Bentuk Lingkungan Permukiman Berdasarkan Sense Of Community di Kelurahan Dadapsari Semarang. Teknik PWK (Perencanaan Wilayah Kota), 2(3), 578586. article. 
Kristiani, M. K., \& Yuliastuti, N. (2014). Sense of Community in Unplanned Settlements: The Role of Public Space Case Study in Dadapsari Village, Indonesia. Semarang: In ICRD.

Kusmayadi, E. S., \& others. (2000). Metodologi penelitian dalam bidang kepariwisataan. Jakarta: Gramedia Pustaka Utama. article.

Lachman, B. (1997). Linking Sustainable Community Activities to Pollution Prevention: A Sourcebook. Santa Monica, CA: RAND. misc.

Papageorgiou-Venetas, A. (1971). Continuity and change: preservation in city planning. Praeger. [Crossref]

Sihombing, A. (2002). Living in the Kampungs: A Firsthand Account of Experiences in Jakarta's Kampungs. In FORUM International Journal of Postgraduate Studies Architecture, Planning and Landscape University of Newcastle (Vol. 7, pp. 15-22). inproceedings.

Talen, E. (1999). Sense of Community and Neighbourhood Form: An Assessment of the Social Doctrine of New Urbanism. Urban Studies, 36(8), 1361-1379. [Crossref]

Vecco, M. (2010). A definition of cultural heritage: From the tangible to the intangible. Journal of Cultural Heritage, 11(3), 321-324. [Crossref]

Widoyoko, E. P. (2012). Teknik penyusunan instrumen penelitian. misc, Yogyakarta: Pustaka Pelajar. 